\title{
In Vitro Safety Pharmacology Profiling of Topical $\alpha$-Adrenergic Agonist Treatments for Erythema of Rosacea
}

\author{
David Piwnica $^{1} \cdot$ Atul Pathak $^{2} \cdot$ Gregor Schäfer $^{3} \cdot$ James R. Docherty $^{4}$
}

Published online: 27 January 2018

(C) The Author(s) 2018. This article is an open access publication

\begin{abstract}
Background Topical $\alpha$-adrenergic agonist therapy has been developed to treat the persistent erythema of rosacea patients. Brimonidine and oxymetazoline are both topical $\alpha$-adrenergic agonists.

Objectives The objective of this in vitro safety pharmacology study was to compare the potential safety profiles of brimonidine and oxymetazoline.

Methods Brimonidine and oxymetazoline underwent pharmacological profiling with a standard panel of 151 assays, including $\alpha$-adrenergic receptors and 5-hydroxytryptamine (5-HT) receptors. A valvular interstitial cell (VIC) proliferation assay was performed with oxymetazoline hydrochloride.

Results Brimonidine was highly selective for the $\alpha_{2}$ adrenergic receptors, specifically $\alpha_{2 A}$, whereas oxymetazoline was found to be much less selective and was highly active against a wide range of targets. Negligible activity was observed with brimonidine at the $5-\mathrm{HT}_{2 \mathrm{~B}}$ receptor, whereas oxymetazoline had significant $5-\mathrm{HT}_{2 \mathrm{~B}}$ receptor agonist activity and caused proliferation of mitral VICs in vitro.

Conclusion As the 5- $\mathrm{HT}_{2 \mathrm{~B}}$ receptor is potentially involved in drug-induced valvulopathy, the benefit/risk ratio should
\end{abstract}

David Piwnica

david.piwnica@galderma.com

Nestle Skin Health R\&D, Sophia Antipolis, France

2 Clinique Pasteur Toulouse, INSERM 1048, Toulouse, France

3 Galderma International, Paris, France

4 Department of Physiology, Royal College of Surgeons in Ireland, Dublin, Ireland be carefully considered, especially in patients with cardiovascular disease or other comorbidities.

\section{Key Points}

Brimonidine and oxymetazoline are both topical $\alpha$ adrenergic agonists that have been developed to treat the persistent erythema of rosacea patients.

Pharmacological profiling showed brimonidine to be highly selective for the $\alpha_{2}$ adrenergic receptors, whereas oxymetazoline was much less selective with a significant number of off-target activities, including the 5-hydroxytryptamine $2 \mathrm{~B}\left(5-\mathrm{HT}_{2 \mathrm{~B}}\right)$ serotonin receptor.

\section{Introduction}

Rosacea is a chronic inflammatory skin disease characterized by transient or persistent central facial erythema and a variety of other signs and symptoms [1,2]. Topical $\alpha$ adrenergic agonist therapy has been developed to treat the persistent erythema of rosacea patients. Oxymetazoline is a direct-acting sympathomimetic amine, an $\alpha_{1}$ and $\alpha_{2}$ adrenergic receptor agonist used as a nasal decongestant $[3,4]$. Brimonidine tartrate is a highly selective $\alpha_{2}$ adrenergic receptor agonist with potent vasoconstrictive activity used as an ophthalmic solution for the initial and long-term management of ocular hypertension and glaucoma [5]. Brimonidine and oxymetazoline are both now approved as 
topical $\alpha$-adrenergic agonists approved for treating erythema of rosacea.

The selectivity (target-based assays and profiling), vasoconstrictive (wire myography assays) and anti-inflammatory (ex vivo human skin model and in vivo inflammation model) properties of brimonidine have previously been demonstrated [6].

The objective of this in vitro safety pharmacology study was to compare the potential safety profiles of brimonidine and oxymetazoline during the drug development process before obtaining long-term safety data.

\section{Materials and Methods}

This in vitro pharmacology research did not involve any human subjects and so did not require IRB review.

\subsection{Receptor Profiling}

Pharmacological profiling was performed with a standard panel (BioPrint ${ }^{\circledR}$ Full Profile, Cerep, Celle l'Evescault, France) of 151 assays, including $\alpha$-adrenergic receptors and 5-hydroxytryptamine (5-HT) receptors [6]. Both compounds were dissolved in dimethyl sulfoxide (DMSO) then diluted in HEPES sodium salt buffer and tested. The amount of a particular substance needed to inhibit by $50 \%$ $\left(\mathrm{IC}_{50}\right)$, or to stimulate by $50 \%$ (half maximal effective concentration $\left.\left[\mathrm{EC}_{50}\right]\right)$, the assay signal was computed from a dose-response assay. A compound was considered active against the target if a $10-\mu \mathrm{M}$ concentration produced $>30 \%$ effect (stimulation or inhibition) on the assay signal.

\subsection{5-Hydroxytryptamine 2B (5-HT $2 \mathrm{~B})$ Agonist Assay}

HEK-293 cells stably expressing human recombinant 5-hydroxytryptamine $2 \mathrm{~B}\left(5-\mathrm{HT}_{2 \mathrm{~B}}\right)$ receptors were maintained in Dulbecco's modified Eagle's medium (DMEM) supplemented with $10 \%$ fetal bovine serum and $250 \mu \mathrm{g} \cdot \mathrm{mL}^{-1} \mathrm{G}-418$. CHO-K1 cells stably expressing the human $5-\mathrm{HT}_{2 \mathrm{~A}}, 5-\mathrm{HT}_{2 \mathrm{~B}}$ or $5-\mathrm{HT}_{2 \mathrm{C}}$ receptors were maintained in Ham's F-12 supplemented with $10 \%$ newborn calf serum and $300 \mu \mathrm{g} \cdot \mathrm{mL}^{-1} \mathrm{G}-418$.

HEK-293 cells expressing human 5-HT $2 \mathrm{~B}$ receptors were seeded in 98-well poly-D-lysine coated plates at a density of 50,000 cells.well ${ }^{-1}$ in DMEM containing $10 \%$ $\left(\mathrm{v} . \mathrm{v}^{-1}\right)$ dialyzed fetal bovine serum and $250 \mu \mathrm{g} \cdot \mathrm{mL}^{-1}$ G-418. After overnight incubation, the cells were washed three times with Hank's buffered saline solution containing $2 \mathrm{mM} \mathrm{CaCl}_{2}, 10 \mathrm{mM}$ HEPES and $2.5 \mathrm{mM}$ probenecid. The cells were incubated with $2 \mu \mathrm{M}$ Fluo-3 AM in Hank's buffered saline solution for $60 \mathrm{~min}$ at $37^{\circ} \mathrm{C}$. The Fluo- 3 loaded cells were then washed four times with Hank's buffered saline solution. Agonist-induced changes in intracellular calcium concentrations were determined at room temperature using a Fluorometric Imaging Plate Reader (Molecular Devices Corporation, Sunnyvale, CA, USA).

\subsection{Valvular Interstitial Cell Proliferation Assay with Oxymetazoline Hydrochloride}

A valvular interstitial cell (VIC) proliferation assay was performed, as described by Setola et al. [7]. VICs were isolated from apparently non-diseased human aortic and mitral valves, obtained from one donor heart deemed unsuitable for transplantation and obtained with appropriate ethical approval and informed consent for research use (Asterand, Royston, Herts, UK). Immediately upon arrival at Asterand, leaflets from the apparently healthy aortic and mitral valves were dissected free of the surrounding heart tissue then digested in a solution of collagenase II in serum-free medium for $20 \mathrm{~min}$. After the 20 -min incubation, the surface of the tissue was rubbed with a sterile cotton swab to remove endothelial cells. The valve tissue was then finely minced and digested in a solution of collagenase III for $4 \mathrm{~h}$. The resulting cell suspension was then filtered, washed and then resuspended in DMEM/Ham's F12 medium supplemented with $10 \%$ fetal bovine serum and $1 \%$ antibiotic-antimycotic solution.

Isolated cells were seeded into T25 flasks and after 4 days the cells were trypsinized and transferred to T75 flasks. When the cells reached approximately $80 \%$ confluency they were trypsinized and seeded into 48-well plates for the proliferation assay.

Cells were incubated in medium containing reduced serum overnight and then exposed to oxymetazoline hydrochloride or DMSO $(0.1 \%)$ for $48 \mathrm{~h}$. One assay was performed corresponding to a single donor and all treatment conditions were in triplicate wells.

Proliferation assay cells were pulsed with [3H] thymidine $\left(2 \mu \mathrm{Ci} \cdot \mathrm{mL}^{-1}\right)$ and assayed for tritium using liquid scintillation counting.

\section{Results}

\subsection{Receptor Profiling}

Brimonidine was highly selective for the $\alpha_{2}$ adrenergic receptors, specifically $\alpha_{2 A}$. Conversely, oxymetazoline was highly active against a wide range of targets, including the $\alpha_{2 \mathrm{~A}}, \alpha_{2 \mathrm{~B}}, \alpha_{2 \mathrm{C}}, \alpha_{1 \mathrm{~A}}$, and $\alpha_{1 \mathrm{~B}}$ adrenergic receptors, as well as 
the $5-\mathrm{HT}_{1 \mathrm{~A}}, 5-\mathrm{HT}_{1 \mathrm{~B}}, 5-\mathrm{HT}_{1 \mathrm{D}}, 5-\mathrm{HT}_{2 \mathrm{~A}}, 5-\mathrm{HT}_{2 \mathrm{~B}}, 5-\mathrm{HT}_{2 \mathrm{C}}$ and $5-\mathrm{HT}_{7}$ serotonin receptors (Fig. 1).

\subsection{5-HT2B Agonist Assay}

Negligible 5-HT $2 \mathrm{~B}$ agonist activity was observed with brimonidine (Fig. 2). Conversely, oxymetazoline demonstrated a potent $5-\mathrm{HT}_{2 \mathrm{~B}}$ agonist effect as the concentration needed to elicit half the maximum biological response $\left(\mathrm{pEC}_{50}:-\log \mathrm{EC}_{50}\right)$ was 7.82 , corresponding to an $\mathrm{EC}_{50}$ of $15 \mathrm{nM}$ (Fig. 2).

\subsection{Valvular Interstitial Cell Proliferation Assay}

Oxymetazoline caused proliferation of passage 2 mitral VICs in vitro; oxymetazoline $(10 \mu \mathrm{M})$ clearly increased $\left[{ }^{3} \mathrm{H}\right]$ thymidine incorporation and oxymetazoline $(100 \mu \mathrm{M})$ approximately doubled the response (Fig. 3).

\section{Discussion}

Although brimonidine and oxymetazoline are both vasoconstrictors, they have very different receptor selectivity. Pharmacological profiling showed brimonidine to be highly selective for the $\alpha_{2}$ adrenergic receptors, specifically $\alpha_{2 \mathrm{~A}}$, whereas oxymetazoline was much less selective with a significant number of off-target activities, including the $5-\mathrm{HT}_{2 \mathrm{~B}}$ serotonin receptor. Since $5-\mathrm{HT}_{2 \mathrm{~B}}$ agonism has been associated with drug-induced valvulopathy, human recombinant $5-\mathrm{HT}_{2 \mathrm{~B}}$ receptor agonist-induced changes in

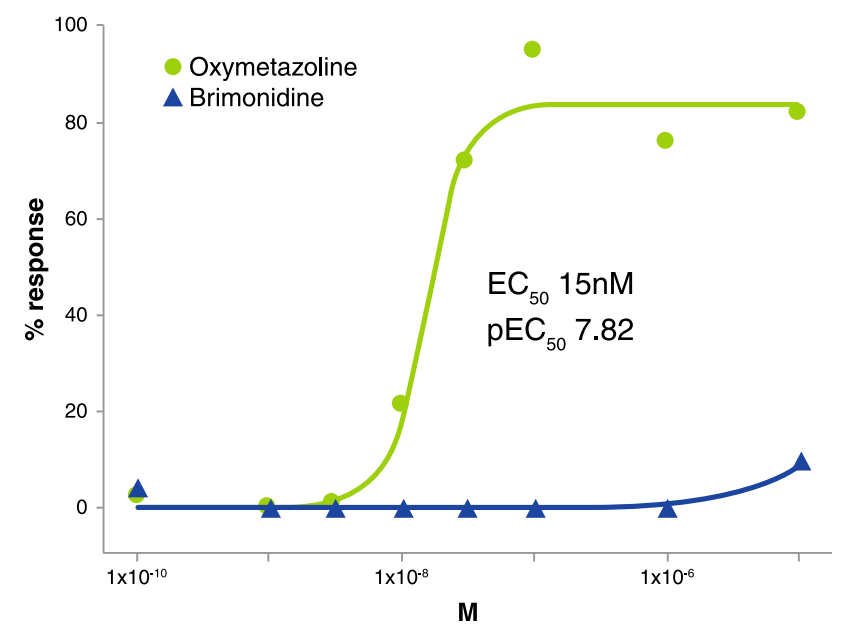

Fig. 2 Hydrochloride 5-hydroxytryptamine $2 \mathrm{~B}\left(5-\mathrm{HT}_{2 \mathrm{~B}}\right)$ agonistinduced changes in intracellular calcium concentrations, measured by fluorescence and expressed as a mean percentage of the control agonist response (assay was carried out in duplicate). $E C_{50}$ half maximal effective concentration, $p E C_{50}-\log E C_{50}$

intracellular calcium concentrations were determined using fluorometric imaging. Negligible 5- $\mathrm{HT}_{2 \mathrm{~B}}$ agonist activity was observed with brimonidine. Conversely, oxymetazoline demonstrated a potent $5-\mathrm{HT}_{2 \mathrm{~B}}$ agonist effect and the $\mathrm{EC}_{50}$ of $15 \mathrm{nM}$ corroborates previously published results [8]. Calcium-based high-throughput screening of 2200 drugs and drug-like compounds found only 27 were $5-\mathrm{HT}_{2 \mathrm{~B}}$ receptor agonists and the authors recommended that five currently prescribed drugs, including oxymetazoline, should be studied further in terms of their pharmacodynamics and potential for valvulopathy [8].

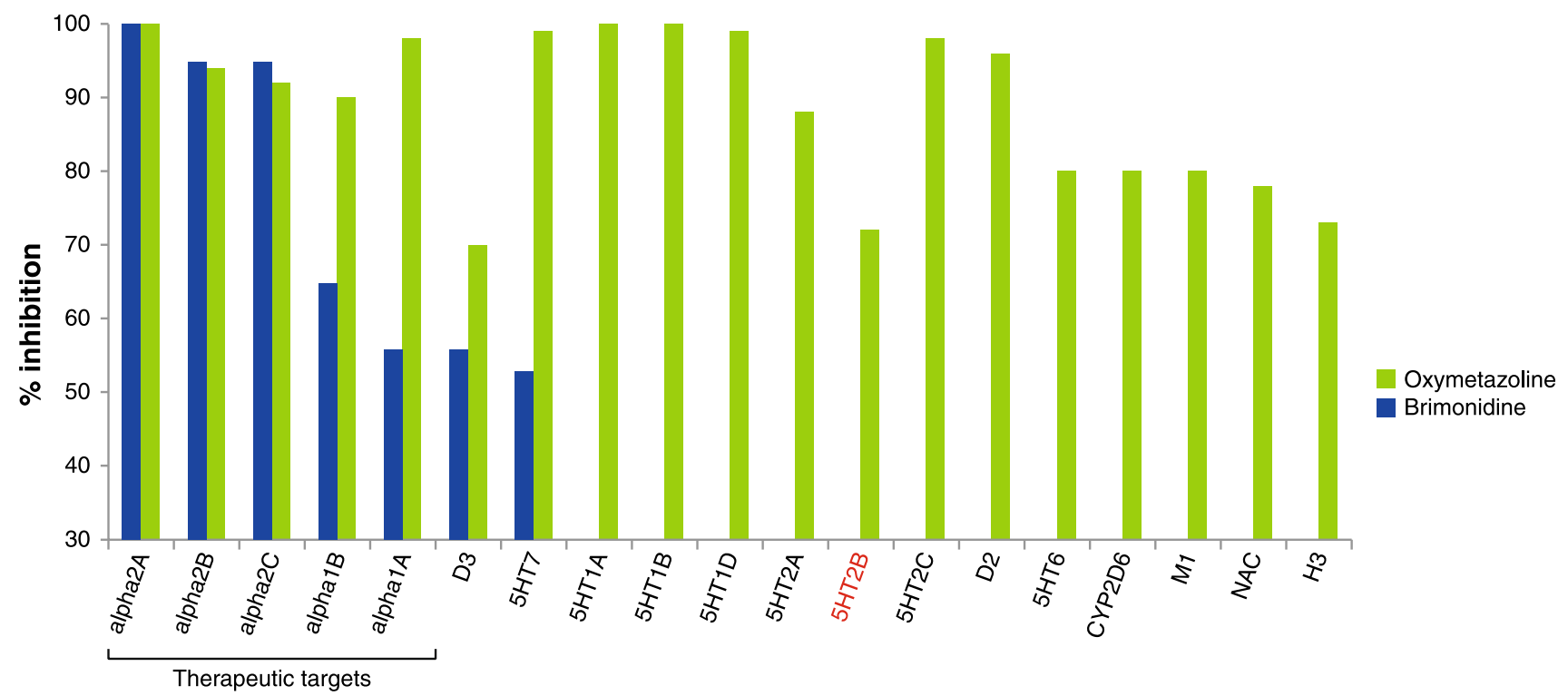

Fig. 1 Receptor profiling of brimonidine and oxymetazoline at $10 \mu \mathrm{M}$ concentration for human $\alpha$-adrenergic receptors and other ligand binding sites. All active targets $(>30 \%$ effect) for brimonidine and/or oxymetazoline are shown and the brimonidine response was normalized on the maximum signal detected in each assay (assay was carried out in duplicate). 5-HT 5-hydroxytryptamine, $D$ dopamine, $C Y P 2 D 6$ cytochrome $\mathrm{P} 450$ 2D6, $M$ muscarinic, $N A C$ $\mathrm{Na}^{+}$channel (site2), $H$ histamine 


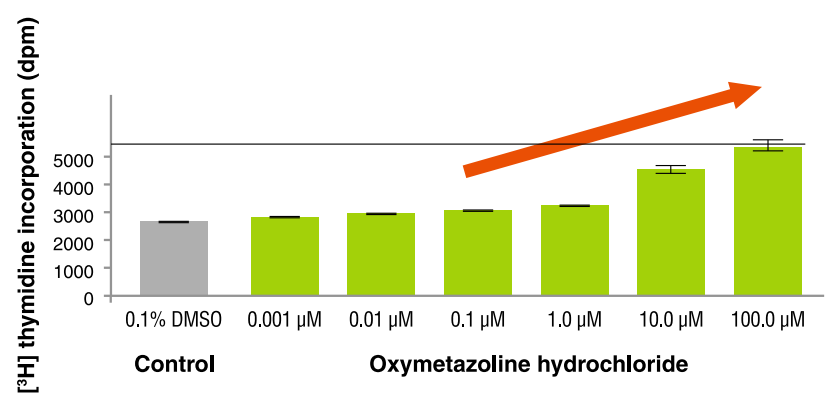

Fig. 3 Effect of oxymetazoline hydrochloride on the proliferation response of valvular interstitial cells (assay in triplicate from a single donor). DMSO dimethyl sulfoxide

An 'off-target' activation of the 5- $\mathrm{HT}_{2 \mathrm{~B}}$ receptor expressed on human heart interstitial cells is a possible mechanism for the pathogenesis of drug-induced valvulopathy [9]. In a VIC proliferation assay, oxymetazoline was shown to cause proliferation of passage 2 mitral VICs in vitro; the VIC proliferation assay was not performed with brimonidine as it is inactive on the $5-\mathrm{HT}_{2 \mathrm{~B}}$ receptor. The use of valvular tissue from a single patient is a limitation of the present study. However, it has been suggested that candidate drug molecules should be screened at $5-\mathrm{HT}_{2 \mathrm{~B}}$ receptors and potent agonists should be avoided, especially for treating non-life-threatening disease and for long-term use since duration of therapy is an important determinant of valvulopathic risk $[8,10]$. Rosacea is a chronic disease so long-term drug use may be desirable. It remains unclear what concentrations are safe and admittedly systemic concentrations from topical treatment may be very low since mean maximum observed systemic concentrations reported for oxymetazoline cream were subnanomolar $(0.4 \mathrm{nM})$ [11]. In that study, patients applied oxymetazoline cream $(0.5,1.0$, or $1.5 \%)$ to the facial area once daily or twice daily for 28 days, and the authors concluded that systemic exposure was minimal [11]. However, even though there may be minimal immediate risk of adverse effects following topical application to the facial area, further studies and post-marketing data are required to determine the relevance of any potential systemic absorption during long-term chronic use.

In conclusion, on the basis of our findings and previous publications, it appears prudent to carefully analyze the benefit/risk ratio when using oxymetazoline in the chronic management of rosacea, especially in patients with cardiovascular disease or other comorbidities.

Acknowledgements The authors thank Helen Simpson, Ph.D., of Galderma for medical writing and editorial support.

\section{Compliance with Ethical Standards}

Funding This study was supported by Nestle Skin Health R\&D, Sophia Antipolis, France.
Ethical approval This article does not contain any studies with human participants or animals performed by any of the authors.

Conflict of interest DP and GS are full-time employees of Nestle Skin Health/Galderma. AP has received consulting fees from Galderma for advisory meetings and manuscript writing and reviewing. JRD has served as an advisory board member for Galderma Laboratories. Galderma markets a brimonidine product for the topical treatment of persistent (nontransient) facial erythema of rosacea in adults 18 years of age or older.

Open Access This article is distributed under the terms of the Creative Commons Attribution-NonCommercial 4.0 International License (http://creativecommons.org/licenses/by-nc/4.0/), which permits any noncommercial use, distribution, and reproduction in any medium, provided you give appropriate credit to the original author(s) and the source, provide a link to the Creative Commons license, and indicate if changes were made.

\section{References}

1. Del Rosso JQ. Advances in understanding and managing rosacea: part 2: the central role, evaluation, and medical management of diffuse and persistent facial erythema of rosacea. J Clin Aesthet Dermatol. 2012;5(3):26-36.

2. Tan J, Almeida LM, Bewley A, Cribier B, Dlova NC, Gallo R, Kautz G, Mannis M, Oon HH, Rajagopalan M, Steinhoff M, Thiboutot D, Troielli P, Webster G, Wu Y, van Zuuren EJ, Schaller M. Updating the diagnosis, classification and assessment of rosacea recommendations from the global ROSacea COnsensus (ROSCO) panel. Br J Dermatol. 2017;176(2):431-8.

3. Smith MB, Feldman W. Over-the-counter cold medications. A critical review of clinical trials between 1950 and 1991. JAMA. 1993;269(17):2258-63 (review).

4. Deckx L, De Sutter AI, Guo L, Mir NA, van Driel ML. Nasal decongestants in monotherapy for the common cold. Cochrane Database Syst Rev. 2016;10:CD009612 (review).

5. Cantor LB. The evolving pharmacotherapeutic profile of brimonidine, an alpha 2-adrenergic agonist, after four years of continuous use. Expert Opin Pharmacother. 2000;1(4):815-34 (review).

6. Piwnica D, Rosignoli C, de Ménonville ST, Alvarez T, Schuppli Nollet M, Roye O, Jomard A, Aubert J. Vasoconstriction and anti-inflammatory properties of the selective $\alpha$-adrenergic receptor agonist brimonidine. J Dermatol Sci. 2014;75(1):49-54.

7. Setola V, Hufeisen SJ, Grande-Allen KJ, Vesely I, Glennon RA, Blough B, Rothman RB, Roth BL. 3,4-Methylenedioxymethamphetamine (MDMA, "Ecstasy") induces fenfluramine-like proliferative actions on human cardiac valvular interstitial cells in vitro. Mol Pharmacol. 2003;63(6):1223-9.

8. Huang XP, Setola V, Yadav PN, Allen JA, Rogan SC, Hanson BJ, Revankar C, Robers M, Doucette C, Roth BL. Parallel functional activity profiling reveals valvulopathogens are potent 5-hydroxytryptamine(2B) receptor agonists: implications for drug safety assessment. Mol Pharmacol. 2009;76(4):710-22.

9. Elangbam CS. Drug-induced valvulopathy: an update. Toxicol Pathol. 2010;38(6):837-48.

10. Roth BL. Drugs and valvular heart disease. N Engl J Med. 2007;356(1):6-9.

11. Kuang A, DuBois J, Ahluwalia G, Zhang S. Clinical pharmacokinetics of oxymetazoline cream following topical facial administration for the treatment of erythema associated with rosacea. Poster presentation at American Academy of Dermatology Annual Meeting, March 20-24, 2015, San Francisco, CA, USA. 